\title{
Blood Corticotrophin Decreased
}

National Cancer Institute

\section{Source}

National Cancer Institute. Blood Corticotrophin Decreased. NCI Thesaurus. Code C78215.

A laboratory test result which indicates decreased levels of corticotrophin in the blood. 